"Assessing information systems success: a respecification of the DeLone and McLean model to integrating the perceived quality"

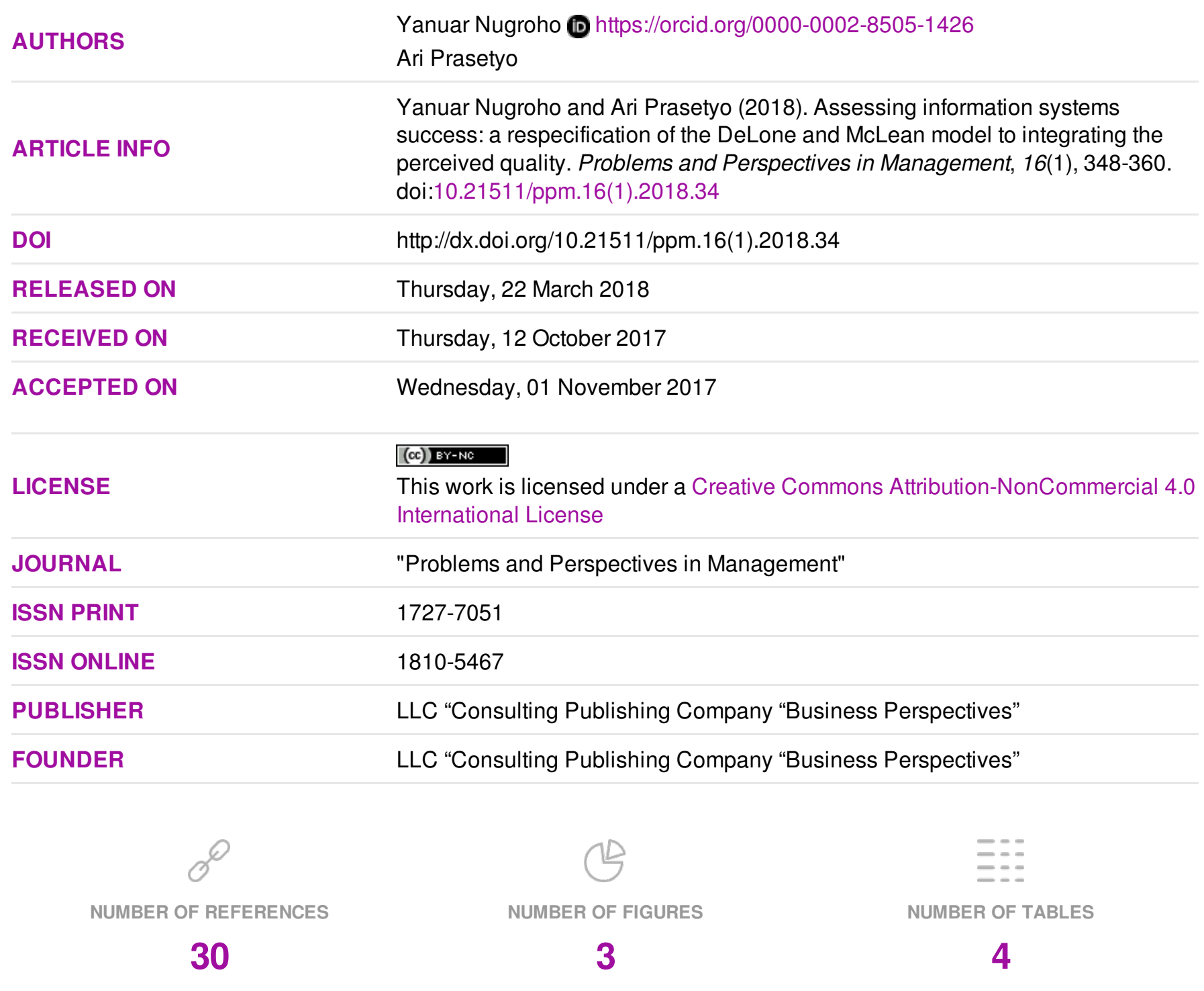

(C) The author(s) 2022. This publication is an open access article. 


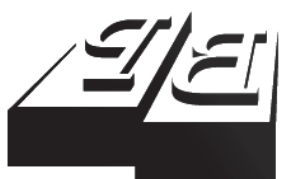

BUSINESS PERSPECTIVES

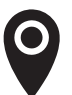

LLC "CPC "Business Perspectives" Hryhorii Skovoroda lane, 10, Sumy, 40022, Ukraine

www.businessperspectives.org

Received on: $12^{\text {th }}$ of October, 2017 Accepted on: $1^{\text {st }}$ of November, 2017

(c) Yanuar Nugroho,

Ari Prasetyo, 2018

Yanuar Nugroho, Department of Business, Faculty of Vocational Education, Universitas Airlangga Surabaya, Indonesia.

Ari Prasetyo, M.Sc., Lecturer of Business Department, Faculty of Vocational Education, Universitas Airlangga, Indonesia.

\section{ASSESSING INFORMATION SYSTEMS SUCCESS: A RESPECIFICATION OF THE DELONE AND MCLEAN MODEL TO INTEGRATING THE PERCEIVED QUALITY}

\begin{abstract}
DeLone and McLean (1992) model of information systems success has received much attention amongst researchers. This study aimed to respecify and validate the DeLone and McLean model (2003) by proposing a social exchange theory for underlying changes in the direction of perceived quality and adding perceived value variables suggested by Wang (2008). The purpose of this study was to obtain a better understanding of information system of the user perception when using organization's information systems. Therefore, a model for testing the information systems success was formed.
\end{abstract}

The primary data used in this study were collected from 102 respondents who apply accounting software in their companies (end-user computing). Companies that were used as samples in this study were the ones that created or developed accounting software by themselves. 27 questionnaires were obtained by mail survey accompanied with a contact-person approach.

All of the hypotheses tested were found to be significantly supported. The model provided strong support for the relationships between perceived quality, perceived value, user satisfaction, and net benefits. Information and system quality has been shown as a proxy that affects service quality. Information quality, system quality, and service quality cause the formation of perceived value and, then, this perceived value will affect user satisfaction and net benefits. The characteristics of information systems are an important aspect that researchers should concern when testing the information systems success.

\section{Keywords}

information system success, social exchange theory, perceived quality, perceived value, user satisfaction, net benefits

\section{JEL Classification M15}

\section{INTRODUCTION}

The implementation of computer-based information systems, in particular accounting information system, has an important role in supporting organization activities. Hence, every organization, either profit or non-pr tain the information systems (Wilkinson et al., 2000). One of the implications of adopting the accounting software by a company is accounting software feature diversity which is often not aligned with enterprise information system reporting requirements. Therefore, it requires further accounting software adaptation by the end users (Tjakrawala \& Cahyo, 2010). When this misalignment occurs, users will have technical barrier experience in the operation that would lead to anxiety that degrades user performance. Consequently, it needs proper analysis to assess the appropriateness of information systems, 
so the huge investment provides useful information system and is also in line with corporate goals.

The research that becomes the starting point of several empirical research studies that examine information systems success is the research conducted by DeLone and McLean (1992), because the model is considered to be quite parsimonious. The DeLone \& McLean IS success model has been updated (2003) and a "service quality" has been proposed by Parasuraman (1988).

This research is important, because there is a paradigm shift in the field of marketing research used in the updated DeLone and McLean model. Therefore, the model needs to be respecified. Currently, a marketing research (Collier \& Bienstock, 2006; Fassnacht \& Koese, 2006; Parasuraman et al., 2005) has not only expanded a perspective on the service quality of information technology, but also focused on the information and system quality designed by the division of IT providers.

The emergence of "service quality" in the DeLone and McLean model (2003) is based on Parasuraman research (1988) in marketing. However, Parasuraman et al. (2005) seek to replace the original size indicator of the service quality dimension with several size indicators contained in the information and system quality. This change indicates in the DeLone and McLean model (2003) that service quality variables are not in parallel with information and system quality.

The development of the use of information technology today not only changed the practice of service, but also changed the conceptual view of service quality. Initial view of the service quality is on the services provided by the information system to its users. Service is a type of interaction between a user and an IT provider in a serving function, particularly in the form of interactions or transactions involving core benefit exchanges such as physical goods, valuable information, and other value-added interactions. From this perspective, the information and system quality is viewed as a resource owned by IT provider who can influence the user's intentions or continue social exchanges with IT provider.

Then, it is required to conduct an empirical testing and theoretical formulations that can lead to the integration of perceived quality that constructs the potential relationship between information quality, system quality, and service quality, because there is very rare research on the information systems that explores service quality based on the basic components of the quality information system, namely information quality and system quality.

Several studies (Essex et al., 1998; Iivari, 2005; Tjakrawala \& Cahyo, 2010) tested the information system success as mandatory for business enterprises. Some of these studies did not consider whether the information system used by a company was an established software used by other companies or this software was created by themselves. The characteristics of this software can become confounding variables in DeLone and McLean information systems success model relation, because this adopted software has been successfully applied by other companies. Furthermore, the fact that there are companies that purchase accounting software from the service provider because not only one company applies this software proves its success based on a reason that other companies also use that software. Compared to the previous research, this research object was the organization which created or developed its own accounting information system that would be used. Generally, this study aimed to respecify DeLone and McLean (2003) model based on theory and literature related to information systems, integrating the perceived quality underlying relationship, which consists of information quality, system quality, and service quality, and also to validate the perceived value variables suggested by Wang (2008). This study also examined whether the software used by the company was successfully implemented by the end user and provided benefits, especially in the companies that created or developed the software independently. 


\section{THEORETICAL FRAMEWORK}

\subsection{The updated DeLone and McLean model (2003)}

Many studies have respecified DeLone and McLean model (1992), like Shaupp et al. (2009), Seddon (1997), Wang (2008), Wu and Wang (2006). DeLone and McLean (2003) have improved the model and proposed the one that has already been updated. This study also answered Seddon's (1997) criticism to validate the "perceived value" which was proposed by Wang (2008), because the perceived value variable has a broader scope than the "perceived usefulness" whose variables were proposed by Seddon (1997).

DeLone and McLean (2003) propose an updated model of information system success by adding "service quality" as a new dimension of the information system success model and grouping all "impact" measures into a single called "net benefits". The constructs of "system use" and "intent to use" are still considered in this model as an important measure. The service quality variable in the updated DeLone and McLean model (2003) based on Parasuraman (1988) used in marketing research.

\subsection{Perceived usefulness versus perceived value}

Perceived value is often conceptualized as the involvement of consumer's assessment in the perceived quality and perceived sacrifice ratio (Zeithaml, 1988). Perceived value is also a function of gaining and providing a component. According to Wang (2008), the function of gaining the component is to obtain benefit or advantage that results from a transaction. Meanwhile, the function of giving/sacrifice is to provide both monetary and non-monetary components in the transaction process.

Thus, perceived value involves a tradeoff between give and get components (Wang, 2008). Meanwhile, perceived usefulness only captures "give" component in a transaction, so this perceived value has a broader scope than Seddon's (1997) criticism which uses perceived variable usefulness.

\subsection{Social exchange theory in the service quality construct}

Currently service is viewed as a dynamic process both by users and IT employees that actively participate (Shostack, 1987). Baroudi and Orlikowski (1988) define service quality as user assessment of attitude and responsiveness of the EDP staff, as well as the quality of their relationship with the EDP staff. Solomon et al. (1985) view interaction between users and IT employees as a form of social exchange which participants normally seek to maximize rewards and minimize transaction cost. This view reflects that there is a social exchange theory in the relationship between users and IT employees.

This research refers to the social exchange theory by Homans (1961) as the theoretical framework developed through cost basis, reward, and reciprocity concept. Cost concept is a work done by IT

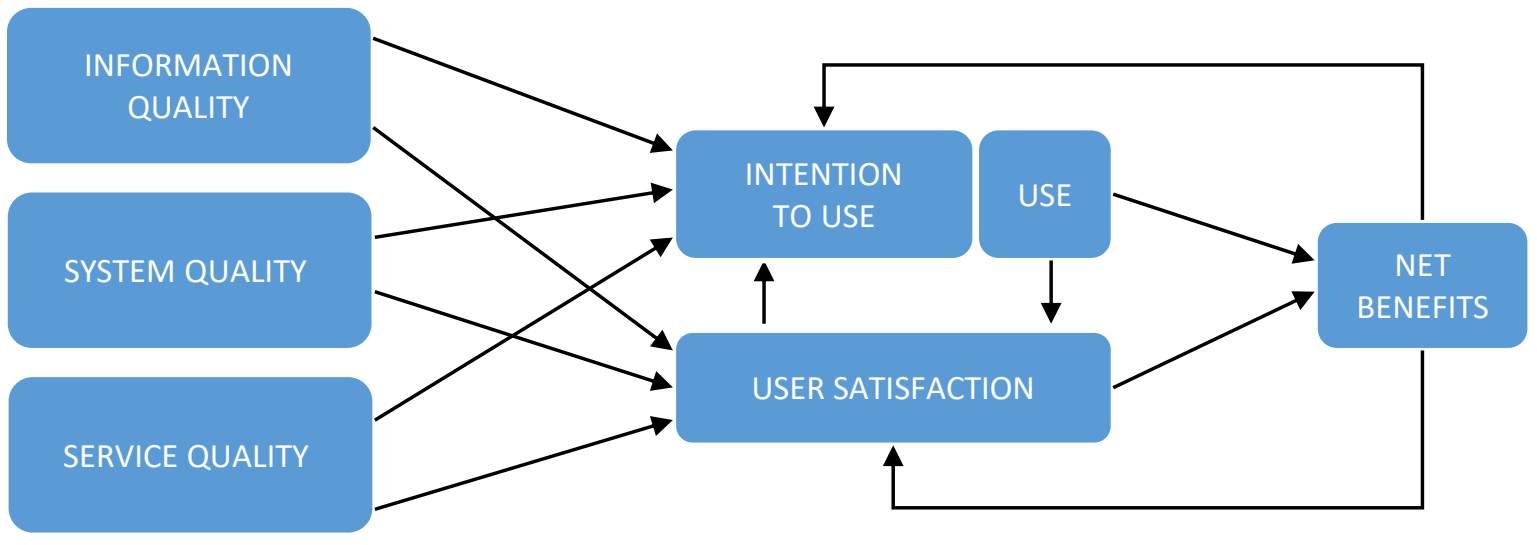

Figure 1. DeLone and McLean (2003) updated IS success model 


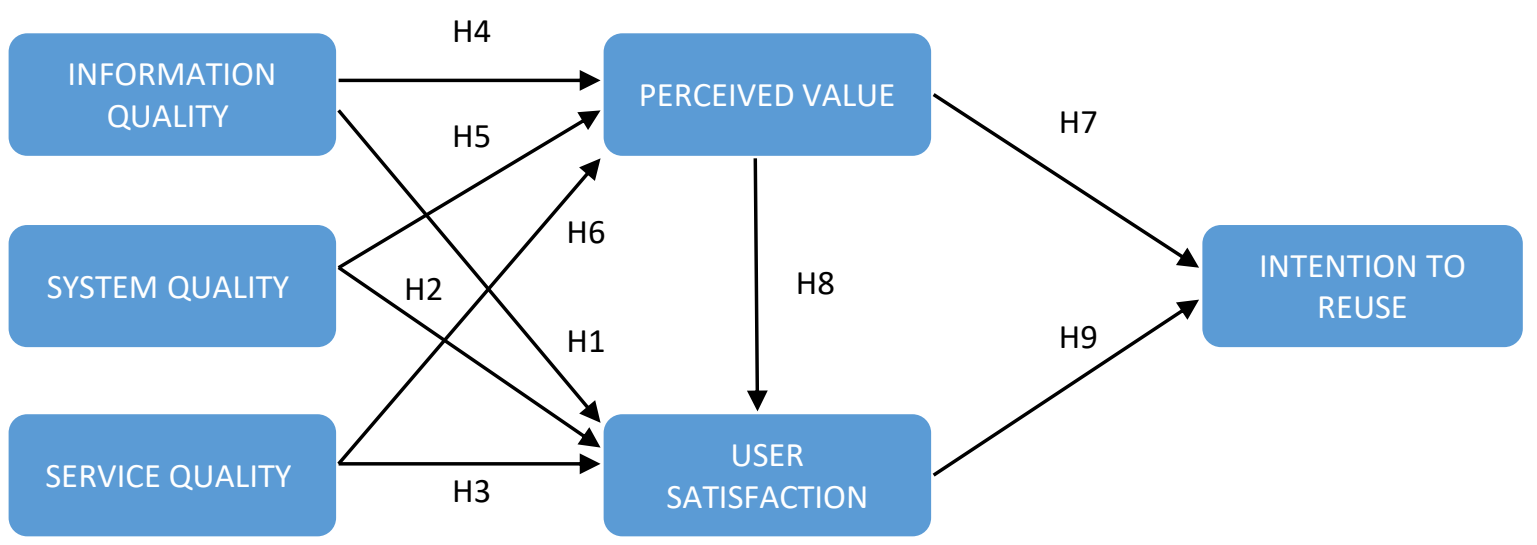

Figure 2. The research model of e-commerce systems success

users to ask the IT provider to provide information and system desired by the users. Reward concept reflected by results obtained by end user because of the responses of IT providers. Meanwhile, reciprocity concept is mutual benefit reciprocal relationship between parties.

According to social exchange theory perspective, exchange occurs between IT providers and information technology users. IT users will perceive the service quality based on the exchange of experience with IT provider. Based on the organization of IT provider's roles and responsibilities, the user service functions include information and products services, application development, training, and maintenance. Information system services are often associated with users when they operate information technology. This information technology has capability to generate information and system designed by IT providers.

Based on the literature review and theory, this research proposed the respecification of assessing information systems success that maintain model as seen in Figure 1.

\subsection{Hypotheses development}

According to social exchange theory perspective, exchange occurs between the unit of IT service providers and users of information technology. Users will perceive the service quality based on the exchange of experience with IT service provider. Information system services are often associated with the users when they operate information technology, which is capable to generating information and system designed by the IT service provider. Information and system quality are viewed as a result of the resources owned by IT service providers. When information system quality is good, the user perceived service quality will also be good. This is because information and system quality are designed by IT provider. Information and system quality is also a solution for IT providers as a response to IT user's demand. Hence, the user will perceive the service quality as the result of system and information provided by IT providers' output. Information output generated by the information system is the design of IT service providers to end users. Therefore, the first hypothesis in this study is:

\section{H1: Information quality will positively affect ser- vice quality.}

Information systems abilities, such as reliable, flexible, responsive, and easy to use, are a product designed by a division of IT service providers. Therefore, the end user will also assess the quality of an information system as a form of service which is provided for him to support the task completion. The second hypothesis in this study is:

\section{H2: System quality will positively affect service quality.}

Teas and Agarwal (2000) research use perceived quality model which caused by antecedents variable of perceived value. Perceived quality hypothesis on perceived value based on Wang (2008) 


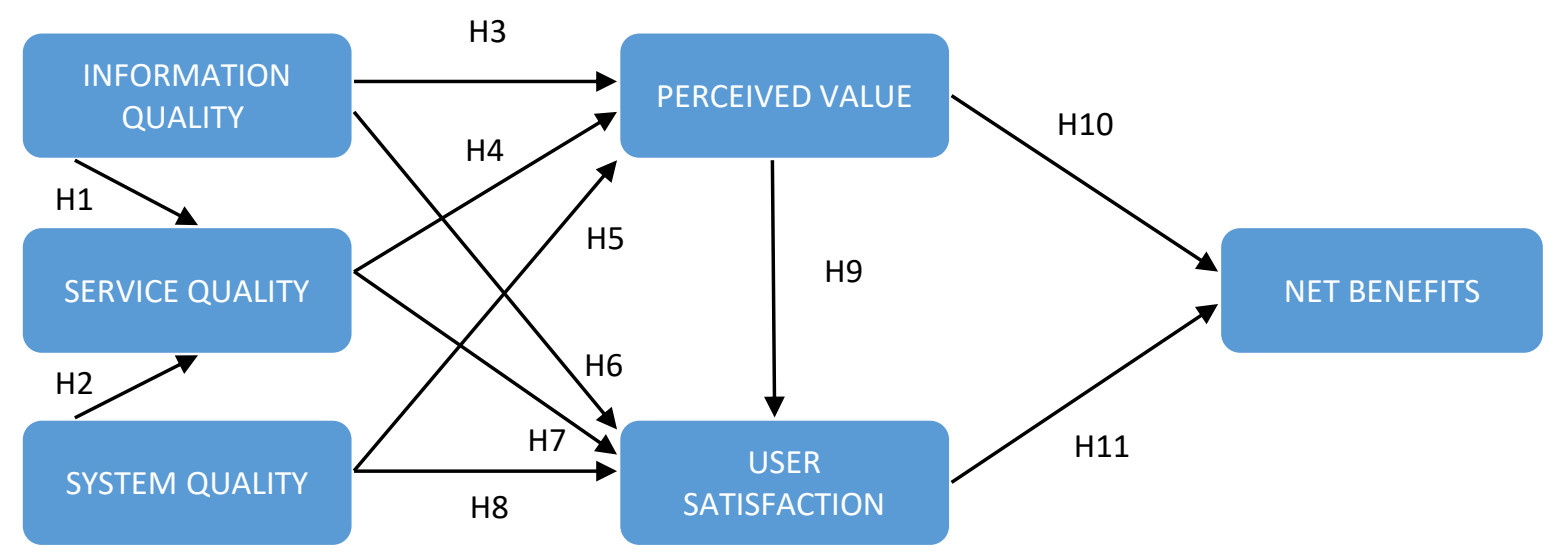

Figure 3. The research model

research, which is IT user perceived quality (information quality, service quality, and system quality), will create perceived value due to tradeoff whether this information technology reduces user task accomplishment value or gives a value. So when perceived quality is good, the perceived value for the user will increase.

Wang (2008) found that information quality has a positive effect on the perceived value of information systems user. When the information generated by the information system is quite accurate, up to date, relevant, complete, and understandable, the users will perceive the information system which is more valuable for them than their effort to obtain that information. So, the third hypothesis in this study is:

\section{H3: Information quality will positively affect per- ceived value.}

In this study, service quality refers to the quality that is provided by IT providers in response to the needs of IT users. DeLone and McLean (2003) proposes five dimensions of service quality measurement, namely tangibility, reliability, responsiveness, assurance, and empathy from the IT service providers. When user perceives this five measurement in the dimensions of service quality well, the user will assess IT service provider performance as a good performance. The fourth hypothesis in this study as follows:

\section{H4: Service quality will positively affect perceived value.}

System quality in this study refers to accounting software's accuracy and efficiency that have a role in generating information. Some of the system quality construct measurements are reliability, responsiveness, flexibility, usability, and accessibility. When operating information system, these all will create user's perception about system whether this system valuable or not for user as primary tasks completion support. Accordingly, the fifth hypothesis formulated in this study is as follows:

\section{H5: System quality will positively affect perceived value.}

End-user satisfaction in this study refers to response of user of accounting software and its output. Chen and Cheng (2009), Rai et al. (2002), Wu and Wang (2006) point out in their research that the information quality has significantly affected end-user satisfaction. Information quality on this study has identified that the information provided by the information system is quite accurate, timely, relevant, complete, and understandable for users. If users can utilize this information to support their work completion, the users will feel satisfied. Therefore, based on the description above, the next hypothesis in this study is:

\section{H6: Information quality will positively affect user satisfaction.}

Chen and Cheng (2009), Wang (2008) in their research found that service quality significantly affects end-user satisfaction. According to Rimawati and Wijanto (2012), along with considering ser- 
vice quality as a strategic goal, it can improve user performance and oriented organizational competitiveness. Service quality concept in this study is the stage at which information system user interacts with the division of IT service providers as a form of service even though this service is not an interpersonal interaction. Therefore, based on that description, the following hypothesis has been constructed.

\section{H7: Service quality will positively affect user satisfaction.}

Chen and Cheng (2009), Rai et al. (2002), Wu and Wang (2006) found that information quality affects end-user satisfaction and that the system quality system is a significant effect on user satisfaction. When information system has a high degree of reliability, accessibility, flexibility, ease of use, and the high level ability response to support user tasks/work completion, the existence of such information systems will satisfy its users. Therefore, the next hypothesis is:

\section{H8: System quality will positively affect user satisfaction.}

Anderson and Mittal (2000) assume that the user satisfaction is the output of user's perceived value obtained in a transaction. That assumption is consistent with the perceived value proposed by Wang (2008), while the user satisfaction is the result of the user's perception of perceived value, so perceived value has a broader concept than the perceived usefulness. Perceived value is a cognitivebased construct that captures the difference between benefits and sacrifices (Wang, 2008). When individual user information systems has good information system perceived value, they will feel that the system information used is quite valuable, and it will give a sense of satisfaction. Because of this, the ninth hypothesis is structured as follows:

\section{H9: Perceived value will positively affect user satisfaction.}

Net benefits are the most important information system success measurements that capture positive and negative balance effects for users, suppliers, user division, IT service providers, organizations, and markets (DeLone \& McLean, 2003).
User perceived value is formed due to the perceived quality. When end users perceive that information system is valuable for them, it will not only have implications for the benefit of individual users and organizations, but also provide wider benefits, because the impact of information systems has been increasing. The next hypothesis that is developed in this study is as follows:

\section{H10: Perceived value will positively affect net benefits.}

Perceived value and user satisfaction are formed due to perceived quality. Halawi et al. (2007), Iivari (2005), McGill and Klobas (2005) prove that user satisfaction has a positive effect on net benefits. When the user is satisfied by the information technology used, it will be useful to help the user task completion and other wider benefits such as corporate business processes, the organization's competitive position, growth in transaction activity, and external organizations. Finally, the next hypothesis which is proposed in this study is as follows:

\section{H11: User satisfaction will positively affect net benefits.}

\section{RESEARCH METHOD}

\subsection{Population and sample research}

Population used in this study was business enterprises on accounting information systems for end user that were create or developed a accounting software independently. This population was used to avoid variable that could be a confounding variable or other relationship causes in DeLone and McLean information systems success model, due to popular accounting software use that was quite successful. Therefore, many companies adopted this accounting software. Confounding variables are variables whose effects disrupt the causal relationship between independent and dependent variables (Hartono, 2012). The effects of these confounding variables must be eliminated to ensure the causal relationship between independent and dependent variables.

Sampling method was snowball sampling, i.e., sampling done by collecting a sample of respon- 
dents from a network reference (Hartono, 2011). At this snowball sampling initial stages, these individuals were discovered and might or might not be selected through probability methods (Cooper \& Schindler, 2011). Then, individuals were used as a connector between researchers with the other individual/groups that have same characteristics, namely end user accounting information systems that created or developed its own accounting software. Selection of this nonprobability sampling method due to the overall population was not available. Data collection used was online-based questionnaire survey.

\subsection{Data analysis technique and hypotheses testing}

This study used a form of Structural Equation Model (SEM). The program used in this study was SmartPLS version 2.0. PLS was used to test the measurement and structural model.

Data collection method in this study used an Internet-based responses, so $t$-test is was necessary to assess the level of time period. Later, the respondents were compared with the earlier ones when answering the questionnaire. This test was carried out with SPSS. If there was no questionnaire response difference between later and earlier respondents, it meant that there was no bias, so the data could be used to answer the research hypothesis. After this $t$-test was done, data was exported into the SmartPLS to start constructs and hypotheses testing.

\section{RESULT}

\subsection{Questionnaire distribution}

After the observations was done, 13 (thirteen) business enterprises that were qualified were found because they created or developed an accounting software independently. To get an accurate sample by sample selection based on proper proxy, this study sample (end users) was assured first through an online questionnaire whether the company built/ developed its own accounting information system. End users' information system accounting was assumed to have full access to information technology and have information system contribution obligation.

Table 1. Value of factor loading the observed variable

\begin{tabular}{|c|c|c|c|}
\hline Observed variable & Factor loading & Observed variable & Factor loading \\
\hline \multicolumn{2}{|c|}{ INFORMATION QUALITY } & \multicolumn{2}{|c|}{ PERCEIVED VALUE } \\
\hline INFO 1 & 0.760 & VALUE 1 & 0.929 \\
\hline INFO 2 & 0.842 & VALUE 2 & 0.943 \\
\hline INFO 3 & 0.818 & VALUE 3 & 0.970 \\
\hline INFO 4 & 0.824 & & \\
\hline INFO 5 & 0.812 & & \\
\hline \multicolumn{2}{|c|}{ SYSTEM QUALITY } & \multicolumn{2}{|c|}{ USER SATISFACTION } \\
\hline SYST 1 & 0.835 & SATIS 1 & 0.898 \\
\hline SYST 2 & 0.849 & SATIS 2 & 0.921 \\
\hline SYST 3 & 0.846 & SATIS 3 & 0.911 \\
\hline SYST 4 & 0.878 & & \\
\hline SYST 5 & 0.883 & & \\
\hline \multicolumn{2}{|c|}{ SERVICE QUALITY } & \multicolumn{2}{|c|}{ NET BENEFITS } \\
\hline SERV 1 & 0.762 & NET 1 & 0.906 \\
\hline SERV 2 & 0.765 & NET 2 & 0.910 \\
\hline SERV 3 & 0.813 & NET 3 & 0.922 \\
\hline SERV 4 & 0.899 & NET 4 & 0.886 \\
\hline SERV 5 & 0.878 & NET 5 & 0.854 \\
\hline SERV 6 & 0.796 & & \\
\hline
\end{tabular}




\subsection{Data analysis}

Before constructing the validity and reliability test, $t$-test was performed first to assess the level of time period of later respondents compared to the earlier respondents in response to a questionnaire to determine whether there was non-response bias or not in responding Internet-based data collection. Based on independent sample t-test, the probability (significance) was 0.172 , greater than 0.05 , meaning that there was no difference between the average group of respondents who filled out the questionnaires earlier and the average group of respondents who filled out a questionnaire later. So there was no non-response bias.

\subsection{Construct validity testing}

Construct validity could be assessed through convergent and discriminant validity. To calculate the convergent validity, this study used factor loading, Average Variance Extracted (AVE), and communality. Observable variables are invalid if it has a standardized factor loading $\geq 0.70$ (Fornell \& Larcker, 1981). Table of test results to assess the factor loading convergent validity is listed below.

Based on Table 1, it appears that all the observed variables have factor of loading values of 0.760 to 0.970 . Based on predefined criteria, the value of factor loading should be $>0.70$, in which convergent validity of all constructs have been met.

In addition, convergent validity testing could be seen from the Average Variance Extracted (AVE) and communality. AVE is a variant of distribution test and indicator construct. Convergent validity was met, because construct had the AVE values > 0.5 (Fornell \& Larcker, 1981) and also communality $>0.5$ (Hartono, 2011). Thus, the items that were used measured the construct in that question.
Table 2. AVE and communality

\begin{tabular}{l|c|c}
\hline & AVE & Communality \\
\hline INFO & 0.659000 & 0.659000 \\
SYST & 0.736650 & 0.736650 \\
SERV & 0.673506 & 0.673506 \\
VALUE & 0.897401 & 0.897401 \\
SATIS & 0.828294 & 0.828294 \\
NET & 0.802693 & 0.802693 \\
\hline
\end{tabular}

Discriminant validity in this study was tested by comparing the extraction variance value between different variables to the average variance of the individual variable (Fornell \& Larcker, 1981). Suggested rule of thumb of loading score was $>0.70$ (Fornell \& Larcker, 1981). The results in Table 3 below show that loading value of construct have higher value than cross loading value in other constructs. The loading values also have values above 0.7 so that discriminant validity has been fulfilled.

Second way to assess the discriminant validity could be measured by comparing square root of Average Variance Extracted (AVE) of each constructs and correlations between constructs models. According to Fornell and Larcker (1981), if the root of the AVE value is higher than the correlations between construct with another constructs models, the conclusion is that it has good discriminant validity.

Table 3 above shows that the AVE roots of each construct has a higher value than the correlation value between constructs to one another. Thus, we can conclude that the indicator items used in this study met the criteria of discriminant validity.

\subsection{Reliability testing}

Reliability can be measured by observing the value of Cronbach's alpha and composite reliability. Cronbach's alpha measures the lower limit value of composite construct reliability while measuring

Table 3. Root of AVE and latent variable correlation

\begin{tabular}{|c|c|c|c|c|c|c|c|}
\hline & Root of AVE & INFO & SYST & SERV & VALUE & SATIS & NET \\
\hline INFO & 0.811788 & 1.000000 & - & - & - & - & - \\
\hline SYST & 0.858283 & 0.447069 & 1.000000 & - & - & - & - \\
\hline SERV & 0.820674 & 0.446323 & 0.521739 & 1.000000 & - & - & - \\
\hline VALUE & 0.947312 & 0.510807 & 0.633968 & 0.671054 & 1.000000 & - & - \\
\hline SATIS & 0.910106 & 0.658287 & 0.725792 & 0.683356 & 0.756770 & 1.000000 & - \\
\hline NET & 0.895931 & 0.586218 & 0.663812 & 0.638651 & 0.749256 & 0.870355 & 1.000000 \\
\hline
\end{tabular}


the true reliability value of a construct. Reliability assessment can be observed from the value of Cronbach's alpha with a minimum threshold of $>0.6$ and composite reliability values with a minimum threshold of $>0.7$ (Hair et al., 2010). The result of reliability values can be observed that the reliability requirements have been met and all variables have a Cronbach's alpha values $(>0.6)$ and composite reliability is more than a minimum threshold $(>0.7)$. Thus, it can be concluded that all the variables have good reliability.

\subsection{Hypotheses testing}

The acceptance standard of the hypothesis significance can apply the comparative value of $T$-statistics and $T$-table. If the value of $T$-statistics in the result is higher than $T$-table, the formed hypothesis can be supported. The rule of thumb is required to support the one tail hypothesis (onetailed) and a standard error of 0.05 by using 6 (six) variables and a sample size of 102 respondents, and the value of the T-table used is 1.660 .

Based on the test results, the value of $T$-statistics on variables that had an influence on others showed a value larger than the value of the T-table, showing the value of $T$-statistics from 2.156 to 9.460 which was higher than 1.660 (T-table). It can be concluded that all the hypotheses proposed in this study are supported.

Table 4. Hypotheses testing results

\subsection{Results}

The analysis conducted on the effect of the information quality on the service quality showed that the coefficient parameter value was 0.266295 and the $T$-statistic value was $2.353\left(\mathrm{t}_{\text {statistic }}>1,660\right)$. The value of $T$-statistics exceeded 1.660 (T-table) that showed the relationship between two variables was significant, while the coefficient of 0.266295 indicated a positive influence between two variables. The result was shown in path coefficients. Therefore, the conclusion on the 1st hypothesis, which states that the information quality positively influences the service quality, was supported.

The results defined that the information quality inside information system was a form of services provided by the IT service provider. Meanwhile, the information generated is a form of information system service responses that was often associated with the operational users of information technology, namely information systems that were able to generate information and system designed by IT service providers.

Second hypothesis test regarding the effect of system quality on service quality was found to have a positive and significant relationship. This was evidenced by the T-statistic value of $3.999\left(t_{\text {statis- }}\right.$ tic $>1,660$ ) and the positive coefficients parameters result whose figure was equal to 0.402687 . It can

\begin{tabular}{|c|c|c|c|c|c|c|c|}
\hline & Variables & $\begin{array}{c}\text { Original } \\
\text { Sample }(O)\end{array}$ & $\begin{array}{c}\text { Sample } \\
\text { Mean (M) }\end{array}$ & $\begin{array}{l}\text { Standard } \\
\text { Deviation } \\
\text { (STDEV) }\end{array}$ & $\begin{array}{l}\text { Standard } \\
\text { Error } \\
\text { (STERR) }\end{array}$ & $\begin{array}{c}\text { T table with } \\
\text { standard error } \\
5 \%,(n=102)\end{array}$ & $\begin{array}{c}\text { T Statistics } \\
(|\mathrm{O} / \mathrm{STERR}|)\end{array}$ \\
\hline $\mathrm{H} 1$ & INFO -> SERV & 0,266295 & 0,274001 & 0,113160 & 0,113160 & \multirow{11}{*}{1.660} & 2,353 \\
\hline $\mathrm{H} 2$ & SYST -> SERV & 0,402687 & 0,407444 & 0,100696 & 0,100696 & & 3,999 \\
\hline $\mathrm{H} 3$ & INFO -> VALUE & 0,173169 & 0,176141 & 0,080301 & 0,080301 & & 2,156 \\
\hline $\mathrm{H} 4$ & SERV -> VALUE & 0,416867 & 0,420019 & 0,093648 & 0,093648 & & 4,451 \\
\hline $\mathrm{H} 5$ & SYST -> VALUE & 0,339054 & 0,322840 & 0,084711 & 0,084711 & & 4,002 \\
\hline $\mathrm{H} 6$ & INFO -> SATIS & 0,285105 & 0,273400 & 0,076161 & 0,076161 & & 3,743 \\
\hline $\mathrm{H} 7$ & SERV $->$ SATIS & 0,209745 & 0,219969 & 0,094461 & 0,094461 & & 2,220 \\
\hline H8 & SYST -> SATIS & 0,318832 & 0,315041 & 0,081324 & 0,081324 & & 3,920 \\
\hline H9 & VALUE -> SATIS & 0,268257 & 0,264715 & 0,070824 & 0,070824 & & 3,787 \\
\hline $\mathrm{H} 10$ & VALUE -> NET & 0,212022 & 0,205958 & 0,087258 & 0,087258 & & 2,429 \\
\hline $\mathrm{H} 11$ & SATIS -> NET & 0,266295 & 0,274001 & 0,113160 & 0,113160 & & 9,460 \\
\hline
\end{tabular}


be concluded that hypothesis 2 , which states that the system quality has positive influence on the service quality, is supported.

The findings of the first and the second hypotheses in this study were formed from the implications of social exchange theory discussed earlier. Information quality and system quality were viewed as a result of the resources owned by IT service providers. Information quality and system quality, as well as a solution of IT service provider, are services as responses towards IT user demand. Therefore, the user would perceive the service quality, result of the system, and the information output provided by IT providers.

The third hypothesis test result showed that the information quality was positively related to perceived value. It was proved from the $t$ statistic value of 2.156 which was above the value of T-table $(>1.660)$ and the positive value of parameter coefficient was 0.173169 . As a resut, the third hypothesis in this study is supported.

These results are consistent with Wang (2008) who proposed the perceived value variable. When the information generated by the information system is quite accurate, timely, relevant, complete, and affordability, the user will perceive the information system valuable to him more than efforts spent to obtain that information. These results indicate that the IT applications are established in order to provide value for its users to be preceded by the creation of an information system that is capable of producing quality information. Positive perceived value can be obtained by providing quality information and involving end users (employees) in the development of IT so that employees have enough information about the function offered by the IT applications.

The fourth hypothesis test indicates that service quality has a positive effect on perceived value. It was proved from the $t$ statistic value of 4.451 which was above the value of T-table $(>1.660)$ and the positive value of the parameter coefficient was 0.416867 , leading to a conclusion that the fourth hypothesis in this study is supported.

Service quality refers to the quality provided by IT service providers in responding to the needs of IT users. Test results are consistent with Wang (2008) which states that service quality has a positive effect on user satisfaction. These results provide information that is important for the organization through IT service providers to not only provide useful information system but also provide value to the user. Thus, the information system is in accordance with the needs of end user in the task completion.

The fifth hypothesis test result suggested that the system quality also gave a positive effect on perceived value. This was evidenced by the T-statistic value of 4.002 which was above the required value of T-table of $>1.660$ and had a parameter coefficient of 0.339054 . Thus, it can be concluded that the fifth hypothesis in this study is supported.

The test results are consistent with the result of Wang (2008) states that end user will tend to judge incumbent system quality. It indicates that organizations must create information technology system that is accurate, efficient, reliable, easy to use, and reachable.

Organizations have to consider about the affective side in the implementation of information systems regarding the end users (employees) on the information systems needs that is valuable in accordance with the expectation. Thus, the end users can maximize the functions of information systems owned.

The sixth hypothesis test result showed that the information quality generated a positive influence towards user satisfaction. It was proved from the $T$-statistic value of 3.743 which was above the value of T-table (> 1.660) and had a coefficient of parameters 0.285105 . Therefore, it can be concluded the sixth hypothesis in this study is supported.

This result is relevant with the previous research which states that the information quality generates positive influence towards user satisfaction (Chen \& Cheng, 2009, Rai et al., 2002; Wu \& Wang, 2006). Information quality is a major predictor that forms the user satisfaction of information systems. Organizations should strive IT division to provide information system that is capable of providing output information that is accurate, timely, relevant, complete, and easy to use. When users can utilize this information to support the completion of its work, they will be satisfied. 
The seventh hypothesis test result showed that service quality has a positive influence on user satisfaction. This was indicated by the $T$-statistic value of 2.220 which was above the value of ttable $(>1.660)$ and had a parameters coefficient of 0.209745 . Thus, it can concluded the seventh hypothesis in this study is supported.

This result is relevant with Chen and Cheng (2009) and Wang (2008) who states that organizations need to consider the service quality as a strategic goal. It aimed to improve organizational performance and excellence-oriented users. The concept of service quality in this study is the step where users interact with the IT service providers as a form of service even though it is not an interpersonal service.

The eighth hypothesis test result showed that the system quality gave a positive influence towards user satisfaction. Based on calculation, it showed that the parameter coefficient value was 0.318832 and the $T$-statistic value was $3.920\left(\mathrm{t}_{\text {statistic }}>1.660\right)$. Value of $t$ statistics exceeding 1.660 (T-table) showed that the relationship between the two variables was significant, while the coefficient of 0.539278 indicated a positive influence between the two variables. Thus, the eighth hypothesis test in this study is supported.

The research result of the eighth hypothesis is consistent with Chen and Cheng (2009), Rai et al., (2002), $\mathrm{Wu}$ and Wang (2006). These results indicate that organizations must create information technology systems that are easy to use, affordable by users, flexible, reliable, and responsive in supporting the completion of the task/job that gives users more satisfaction than making an information system that is powerful in its functionality, but not easy to use.

The test of the ninth hypotheses about the influence of the perceived value against the user satisfaction was found positive and significant. This was evidenced by the $t_{\text {statistic }}$ value of $3.787\left(t_{\text {statis- }}\right.$ tic $>1.660)$ and the coefficients were positive pa- rameters that is equal to 0.268257 . It can be concluded that the ninth hypothesis which states that perceived value has a positive effect on user satisfaction is supported.

The test result is consistent with Wang studies (2008). This result provides important information for organizations to create a system that is not only useful but also provides value for its users to create a high user satisfaction. A high level of employee satisfaction is one of the primary parameters of information technology investments success that can give a positive impact.

The tenth hypothesis test result showed that the perceived value had a positive effect on net benefits. This result was indicated by the $t_{\text {statistic }}$ value of 2.429, which was above the required value of $t_{\text {table }}(>1.660)$ and had a parameter coefficient 0.212022 . Thus, the 10th hypothesis in this study is supported.

The results of this study explain that, when end user found that information system is valuable, it not only affects the individual but also affects for the organization and for external organizations that affect towards competitive advantage and business efficiency.

The eleventh hypothesis testing showed that user satisfaction had a positive effect on net benefits. It was proved from the $t_{\text {statistic }}$ value of 9.460 which was higher than the value of $t_{\text {table }}(>1.660)$ and the value of the parameter coefficient indicated a positive value of 0.709904 . Thus, the eleventh hypothesis in this study is supported.

This hypothesis supports Halawi et al. (2007), Iivari (2005), McGill and Klobas (2005). User satisfaction related to experiencing information technology will be useful to help the user task completion and other benefits. It indicates that organizations need to pay attention to any indicators that needs to be achieved from the implementation of information systems.

\section{CONCLUSION}

The research results concluded three important things. First, the information and system quality is proved to be a proxy that affects service quality. This study successfully respecify the DeLone and McLean model (2003) by changing the effect direction of perceived quality structures consisting of information quality, system quality, and service quality. It indicates that the proposed social 
exchange theory can be the theoretical foundation of integrating relationship information quality, system quality, and service quality in information systems success model as a paradigm shift in marketing research in 2005. Second, information quality, system quality, and service quality are the causes of the formation of perceived value and the value will affect the perceived user satisfaction and net benefits. This study validates the variable of "perceived value" proposal of Wang (2008) by replacing the variable of "use/using" the original model of DeLone and McLean (2003). Thus, perceived value of the information system success model is a variable that has a broader scope than the variable uses/use of dynamic proxies in information quality, system quality, service quality, user satisfaction, and net benefits. Third, the characteristic of information systems is an important aspect with which researchers should be concerned in testing the information systems success. The characteristic of information system is already popular and can distract the test of information systems success.

\section{Limitations and suggestions}

The information system test has to distinguish company characteristics, such as firm size companies, with sensitivity test. Because a company has more transaction activities than a small firm, more powerful accounting information systems are required than the small firms. The differences of the information systems may lead to differences in the perception of information systems use. Future research has to test the information systems success model in the sample of the same company characteristics at the same size to get better results to anticipate the information bias. Alternatively, it can also compare the results of research by using the company's specific characteristics compared to other characteristics to determine whether there is a difference in proxy response rate inside an information system success model.

Due to time constraints, only 13 companies that used the accounting information systems research sample were found. Furthermore, the higher number of accounting information systems is required to increase the external validity. Future research is expected to test the research model on a broader sample and the accounting information systems that are tested more various to obtain a better external validity. The model also needs to be tested in other information systems except for the accounting information system.

Data were collected in this study by using snowball sampling technique. Furthermore, researchers tend to be able to have less control to the conditions of the respondents to reduce biases that may occur. Future research should use other data collection techniques that are able to reach the respondents and can anticipate the bias that occurs.

Measurement methods in this study used items based on user perception which can potentially create a bias, because the measurement occurs towards construct based on the viewpoint of each respondent. Future research should attempt to close the gap between perception and actual conditions with the guidance the respondents in order to understand the overall intent of the questions in the questionnaire. In addition, further research also can use actual measurements. Thus, there is no comparison between the respondent's perception and the actual measurement objective.

The model proposing the information systems success leads to a tendency of the whole hypothesis acceptance because of all of the variables are the ones that have a high correlation to the user model. To handle the rise of the response bias, the development of a questionnaire instrument is required to change the patterns of response to the questionnaire answers that is not uniform, such as not all of score of 1 means "strongly disagree" and or change the direction of questionnaire statement with nonuniform patterns, namely the positive and negative statements. 


\section{REFERENCES}

1. Anderson, E. W., \& Mittal (2000). Strengthening the Satisfaction-Profit Chain. Journal of Service Research, Nov(3), 170-120. Retrieved from http://journals.sagepub.com/doi/ abs/10.1177/109467050032001

2. Baroudi, J. J., \& Orlikowski, W. J. (1988). A Short-Form Measure of User Information Satisfaction: A Psychometric Evaluation and Notes on Use. Journal of Management Information Systems, 4(4), 44-59.

3. Chen, \& Cheng (2009). Understanding consumer intention in online shopping: a respecification and validation of the DeLone and McLean model. Behaviour \& Information Technology, 28(4), 335-345.

4. Collier, J. E., \& Bienstock, C. C. (2006). Measuring Service Quality in E-Retailing. Journal of Service Research, 8(3), 260-275. Retrieved from http://journals.sagepub.com/ doi/abs/10.1177/1094670505278867

5. Cooper, D. R., \& Schindler, P. S. (2011). Business Research Method. McGraw-Hill: Singapore.

6. DeLone, W. H., \& McLean, E. R. (2003). The DeLone and McLean Model of Information Systems Success: A Ten-Year Update. Journal of Management Information Systems, 19(4), 9-30.

7. DeLone, W. H., \& McLean, E. R. (1992). Information Systems Success: The Quest for the Dependent Variable. Information System Research, 3(1), 66-95. Retrieved from https://pdfs.semanticscholar.org/a0 41/45f1ca06c61f5985ab22a2346b78 8f343392.pdf

8. Essex, P. A., et al. (1998). Determinants of Information Center Success. Journal of Management Information Systems, 15(2), 95-117.

9. Fassnacht, M., \& Koese, I. (2006). Quality of Electronic Services: Conceptualizing and Testing a Hierarchical Model. Journal of Service Research, 9(1), 19-37.

10. Fornell, C., \& Larcker, D. F. (1981). Evaluating Structural Equation Models with Unobservable Variables and Measurement Error.
Journal of Marketing Research, 18, 39-50.

11. Hair, J. F. et al. (2010). Multivariate Data Analysis-A Global Perspective. ( $7^{\text {th }}$ ed.). Pearson: New Jersey.

12. Halawi, L. A. et al. (2007). An Empirical Investigation of KnowledgeManagement Systems Success. The Journal of Computer Information Systems, 48(2), 121-135.

13. Hartono, J. (2012). Metode Penelitian Bisnis: Salah Kaprah dan Pengalaman-Pengalaman. Yogyakarta: BPFE.

14. Hartono, J. (2011). Konsep dan Aplikasi Structural Equational Modeling (SEM) Berbasis Varian dalam Penelitian Bisnis. Yogyakarta: UPP STIM YKPN.

15. Hartono, J. (2011). Pedoman Survei Kuesioner: Pengembangan Kuesioner, Mengatasi Bias, dan Meningkatkan Respon. Yogyakarta: BPFE.

16. Iivari, J. (2005). An Empirical Test of the DeLone-McLean Model of Information System Success. Advances in Information Systems, 36, 8-27. Retrieved from https://dl.acm. org/citation.cfm?id=1066152

17. McGill, T., \& Klobas, J. (2005). The Role of Spreadsheet Knowledge in User-Developed Application Success. Decision Support Systems, 39(3), 355-369.

18. Parasuraman et al. (2005). E-SQUAL: A Multiple-Item Scale for Assessing Electronic Service Quality. Journal of Service Research, 7(3), 213-233.

19. Parasuraman, A. et al. (1988). SERVQUAL: A Multiple-Item Scale for Measuring Consumer Perceptions of Service Quality. Journal of Retailing, 64(1), 12-40.

20. Rai et al. (2002). Assessing the Validity of IS Success Models: an Empirical Test and Theoretical Analysis. Information Systems Research, 13, 50-69. Retrieved from https://pubsonline.informs.org/doi/ abs/10.1287/isre.13.1.50.96

21. Rimawati, Y., \& Wijanto, S. R. (2012). Keberhasilan Implementasi Elektronik Government Berdasar- kan Persepsi Pengguna. Simposium Nasional Akuntansi XV.

22. Seddon, P. B. (1997). A Respecifation and Extension of the DeLone and McLean Model of IS Success. Information Systems Research, 8(3), 240-253.

23. Shostack, G. L. (1987). Service Positioning Through Structural Change. Journal of Marketing, 51, 34-43.

24. Solomon, M. R. et al. (1985). A Role Theory Perspective on Dyadic Interactions: The Service Encounter. Journal of Marketing, 49, 99-111. Retrieved from http://www.ida.liu.se/ steho87/ und/htdd01/5002883.pdf

25. Teas, R. K., \& Agarwal, S. (2000). The Effects of Extrinsic Product Cues on Consumers' Perceptions of Quality, Sacrifice, and Value. Journal of Academy of Marketing Science, 28, 278-290.

26. Tjakrawala, F. X. K., \& Aldo, C. (2010). Adaptasi Model DeLone \& McLean yang Dimodifikasi Guna Menguji Keberhasilan Impelementasi Software Akuntansi bagi Individu Pengguna: Studi Empiris pada Perusahaan dalam Industri Barang Konsumsi yang Terdaftar di BEI. Simposium Nasional Akuntansi XIII, Purwokerto.

27. Wang, Y. S. (2008). Assessing E-Commerce Systems Success: a Respecification and Validation of The DeLone and McLean model of IS Success. Information Systems Journal, 18, 529-557.

28. Wilkinson, J. W. et al. (2000). Accounting Information Systems: Essential Concepts and Applications. ( $4^{\text {th }}$ ed.). New York: John Wiley \& Sons Inc.

29. Wu, J. H., \& Wang, Y. M. (2006) Measuring KMS Success: A Respecification of The DeLone and McLean's Model. Information and Management, 43, 728-739. Retrieved from https://pdfs.semanticscholar.org/59a1/6670c3b2822b 51882422bf0675f4f26c60da.pdf

30. Zeithaml, V. A. (1988). Consumer Perceptions of Price, Quality, and Value: a Means-end Model and Synthesis of Evidence. Journal of Marketing, 52, 2-22. 